\author{
A Diallo $^{1 *}, \mathrm{M} \mathrm{Eliassou}^{1}, \mathrm{~K}$ Djadou $^{2}, \mathrm{Y}$ \\ Potchoo $^{3}$ and EE Creppy ${ }^{1}$ \\ ${ }^{1}$ Department of Toxicology, Faculty of Health \\ Sciences, University of Lome, Togo \\ ${ }^{2}$ Department of Pediatrics, Faculty of Health \\ Sciences, Université de Lomé, Togo \\ ${ }^{3}$ Department of Pharmacololy, Faculty of Health \\ Sciences, University of Lome, Togo \\ Dates: Received: 28 January, 2016; Accepted: 24 \\ February, 2016; Published: 01 March, 2016 \\ *Corresponding author: A Diallo, Department of \\ Toxicology, Faculty of Health Sciences, University of \\ Lome, 05 BP: 216 lome, Togo, Tel: +22890113723; \\ E-mail: aboudoulatif@gmail.com \\ www.peertechz.com \\ ISSN: 2455-5282
}

\author{
Case Report
}

\section{Accidental Acute Poisoning of two Children by Paracetamol-Codeine (1000 Mg/60 Mg) Association - A Case Report}

\section{Introduction}

Paracetamol is one of the most used drugs in the world [1] It's also one of the most common drugs that children accidentally ingest. Unlike the situation in adults, death and hepatotoxicity in children from paracetamol poisoning are exceedingly uncommon events [2]. After ingestion it is rapidly and completely absorbed from the gastrointestinal tract. Approximately $85-95 \%$ of the absorbed paracetamol is metabolized by the liver and excreted in the urine as nontoxic metabolites. About 5 to $15 \%$ of paracetamol ingested is metabolized by cytochromes P-450 in toxic metabolite, N-acetyl para-quinoneimine, a very toxic compound, which is detoxified by glutathione present in the liver with glutathione $S$ - transferase. In massive intoxication with paracetamol, glutathione detoxification capacity is exceeded. This leads to hepatocellular necrosis with the release of liver enzymes in the blood [3]. Paracetamol is a major cause of fulminant hepatitis [4], occurring 24 to 48 hours after the onset of poisoning.

But codeine is a morphinomimetic produced after the metabolism of morphine [5]. It is used in the treatment of pain. Unlike paracetamol poisoning, poisoning by an association of paracetamol and codeine are not well documented, especially those of children.

The management of poisoning is difficult in my country because of the lack of material for the realization of toxicological analysis. We describe in this paper, two cases poisoning of children less than 3 years. Who accidentally received following a delivery error by two pharmacies, an adult form of rectal suppository containing paracetamol-codeine $(1000 \mathrm{mg} / 60 \mathrm{mg})$.

\section{Observation}

Both intoxicated children, the first 2 years old and the second 3-year old were suffering from malaria. After a consultation in the Medical Center of the Police of Lomé (Togo), paracetamol rectal suppository was prescribed. Unfortunately the pharmacies have delivered the adult form of paracetamol-codeine (1000 mg paracetamol and $60 \mathrm{mg}$ codeine) rectal suppository, instead of the child form.

Apart from other prescribed drugs like antimalarial and antibiotic, the child 1 ( 2 years old) has received one rectal suppository in the morning and one in the evening for 2 days that is to say $154 \mathrm{mg} / \mathrm{kg}$ of paracetamol and $9 \mathrm{mg} / \mathrm{kg}$ of codeine per day.

A persistent fever $\left(39^{\circ} \mathrm{C}\right)$, associated to an asthenia, vomiting, sweating and especially abdominal pain is identified on the child 1 during the examination. There was also an abdominal guarding during palpation of the abdomen. The results of laboratory tests have shown an increase in transaminases $(\mathrm{ALT}=2179 \mathrm{IU} / \mathrm{L}, \mathrm{AST}=$ $1800 \mathrm{IU} / \mathrm{L}), \gamma$-glutamyl transferase (GGT = $109 \mathrm{IU} / \mathrm{L})$; microcytic hypochromic anaemia with normal sedimentation rate and negative Widal serodiagnosis (Table 1). Alkaline phosphatase was slightly elevated indicating a cholestasis associated with a hepatotoxicity. The toxicological analysis of urine by thin layer chromatography (TLC) has showed the presence of paracetamol. Because of the lack of material for the realization of toxicological analysis the paracetamol levels in the blood were not done. The analysis of feces was normal.

The treatment of the intoxication has consisted initially in a release of all the drugs and an administration of metamizole and $\mathrm{N}$-acetylcysteine. The dose of $\mathrm{N}$-acetylcysteine administered orally, is $140 \mathrm{mg} / \mathrm{kg}$ followed by $70 \mathrm{mg} / \mathrm{kg}$ every 4 hours for 10 days. After one week of treatment, abdominal pains have disappeared. After 10 days transaminases and GGT were back to normal.

Unlike the child 1 , the child 2 ( 3 years old $/ 13 \mathrm{~kg}$ ) has received 
Table 1: Biochemical and hematological parameters of Child 1 on day 1 and day 10 after an accidental acute poisoning by a paracetamol-codeine $(1000 \mathrm{mg} / 60$ mg) association.

\begin{tabular}{|c|c|c|c|}
\hline Parameters & Day 1 & Day 10 & Reference rangers \\
\hline AST (U/L) & 2179 & 53 & $M: \leq 38 \mathrm{UI} / \mathrm{L} \quad \mathrm{F}: 31 \leq \mathrm{UI} / \mathrm{L}$ \\
\hline ALT (U/L) & 1800 & 53 & $M: \leq 40 \mathrm{UI} / \mathrm{L} \quad \mathrm{F}: 32 \leq \mathrm{UI} / \mathrm{L}$ \\
\hline GGT (U/L) & 109 & 82 & $M: \leq 11-50$ UI/L $F: 7-32 \leq U I / L$ \\
\hline $\begin{array}{l}\text { Alkaline phosphatase } \\
(\mathrm{U} / \mathrm{L})\end{array}$ & 420 & 382 & $\begin{array}{l}\text { Adulte:98-279UI/L Child:245-768 } \\
\text { UI/L }\end{array}$ \\
\hline Haemoglobin (g/dL) & 11 & 11 & $12-14 \mathrm{~g} / \mathrm{dl}$ \\
\hline Haematocrit (\%) & 35,2 & 35 & $36-44 \%$ \\
\hline $\operatorname{MCV}(\mathrm{fl})$ & 70 & 71 & $74-88 \mathrm{fl}$ \\
\hline $\mathrm{MCH}(\mathrm{pg})$ & 21,9 & 22 & $27-31 \mathrm{pg}$ \\
\hline $\mathrm{MCHC}(\%)$ & 31,3 & 32 & $32-36 \mathrm{~g} / \mathrm{dl}$ \\
\hline 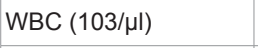 & 9300 & 8000 & $5000-13000 / \mathrm{mm} 3$ \\
\hline Platelet $(103 / \mu \mathrm{L})$ & 325000 & 400000 & $150000-450000 / \mathrm{mm} 3$ \\
\hline
\end{tabular}

ALT: Alanine Aminotransferase, AST: Aspartate Aminotransferase and GGT: Gamma Glutamyl Transpeptidase.

Table 2: Biochemical and hematological parameters of Child 2 on day 1 and day 3 after an accidental acute poisoning by a paracetamol - codeine $(1000 \mathrm{mg} / 60$ mg) association.

\begin{tabular}{|c|c|c|c|}
\hline Parameters & Day 1 & Day 3 & Reference rangers \\
\hline AST (U/L) & 29 & 27 & $M: \leq 38 \mathrm{UI} / \mathrm{L} \quad \mathrm{F}: 31 \leq \mathrm{UI} / \mathrm{L}$ \\
\hline $\operatorname{ALT}(\mathrm{U} / \mathrm{L})$ & 15 & 15 & $M: \leq 40 \mathrm{UI} / \mathrm{L} \quad \mathrm{F}: 32 \leq \mathrm{UI} / \mathrm{L}$ \\
\hline GGT (U/L) & 30 & 20 & $\begin{array}{l}M: \leq 11-50 \text { UI/L } \quad F: 7-32 \leq \\
U I / L\end{array}$ \\
\hline Alkaline phosphatase (U/L) & 421 & 534 & $\begin{array}{l}\text { Adulte:98-279UI/L } \\
\text { Child:245-768 UI/L }\end{array}$ \\
\hline Haemoglobin (g/dL) & 7,5 & 7,1 & $12-14 \mathrm{~g} / \mathrm{dl}$ \\
\hline Haematocrit (\%) & 25,10 & 23,6 & $36-44 \%$ \\
\hline $\operatorname{MCV}(\mathrm{fl})$ & 72,50 & 72 & $74-88 f l$ \\
\hline $\mathrm{MCH}(\mathrm{pg})$ & 21,70 & 21,6 & $27-31 \mathrm{pg}$ \\
\hline $\mathrm{MCHC}(\%)$ & 29,90 & 30,1 & $32-36 \mathrm{~g} / \mathrm{dl}$ \\
\hline WBC $(103 / \mu \mathrm{l})$ & 8500 & 5800 & $5000-13000 / \mathrm{mm} 3$ \\
\hline Platelet $(103 / \mu \mathrm{L})$ & 105000 & 211000 & $150000-450000 / \mathrm{mm} 3$ \\
\hline
\end{tabular}

ALT: Alanine Aminotransferase, AST: Aspartate Aminotransferase and GGT: Gamma Glutamyl Transpeptidase.

the rectal suppository discontinuously for several days, once a day or once every 2 days. After three weeks of treatment with the suppository (and other drugs like antimalarial and antibiotic), the persistence of the fever $\left(39^{\circ} \mathrm{C} 6\right)$ associated with coughing, bloating, abdominal pain and defense on palpation; have caused a further consultation in the same care center. The questioning and the experience with the child 1 , two weeks earlier, have helped immediately to suspect an error in drug delivery by the pharmacy. The results of biological analysis have revealed microcytic hypochromic anaemia, a mild thrombocytopenia and a normal erythrocyte sedimentation rate (ESR). Transaminases and GGT were subnormal and alkaline phosphatase values were slightly high, indicating a consecutive cholestasis inhibition of ATPase pumps in the bile ducts. The other biochemical parameters and the sonography were normal (Table 2). Thin Layer Chromatography showed the presence of paracetamol in the urine. The analysis of stool was normal.

The treatment has consisted in stopping the suppository and administering the $\mathrm{N}$-acetylcysteine to increase the glutathione pulse and the metamizole to fight against fever. After one week the cough and abdominal pain have ceased. An anti-anemia treatment was then introduced. A month later the children's condition returned to normal.

\section{Discussion}

Normal therapeutic dose of paracetamol is $60 \mathrm{mg} / \mathrm{kg}$ for adults and 20 to $50 \mathrm{mg} / \mathrm{kg}$ for children. Severe poisoning in children manifests that above $150 \mathrm{mg} / \mathrm{kg}$ [3]. Child 2 (3 years old $/ 13 \mathrm{~kg}$ ) who has received high doses of paracetamol and codeine discontinuously was apparently not severely intoxicated. Poisoning of the 2 children although due to a combination of two active ingredients, paracetamol and codeine, only the toxic effect of paracetamol was observed. Other drugs used for the treatment of malaria (arthemether) and anaemia (iron and vitamins) are used correctly and are not responsible of liver poisoning. The paracetamol poisoning is manifested by the increase of child 1' liver enzymes (transaminases, GGT) and abdominal pain. A discrete cholestasis associated with a hepatic cytolysis is observed in relation to the increase in alkaline phosphatase. The presence of anaemia may not be related to the paracetamol poisoning, because anaemia is endemic in Africa due to malaria [6,7].

The toxic effects of codeine (toxic threshold: $2 \mathrm{mg} / \mathrm{kg}$ ), such as depression of the central nervous system (CNS) have not been observed during these intoxications however the two children had a marked lethargy and fatigue. Pancreatitis reported during poisoning by paracetamol-codeine combination was not observed $[8,9]$. Amylases were not assayed.

The unavailability of the injectable form of the $\mathrm{N}$-acetylcysteine has led us to use the oral form, available in pharmacies to treat coughs. The oral route is also the practice in USA [10]. Wallace and his team published the only evidence-based flowchart in 2002 and was accepted by the Royal College of Paediatrics and Child Health as a Good Practice Consensus Statement. The dose is $150 \mathrm{mg} / \mathrm{kg}$ in 3 $\mathrm{ml} / \mathrm{kg}$ of $5 \%$ dextrose over 15 minutes, followed by $50 \mathrm{mg} / \mathrm{kg}$ in $7 \mathrm{ml} /$ $\mathrm{kg} \mathrm{5 \%}$ dextrose over 4 hours followed by $100 \mathrm{mg} / \mathrm{kg}$ in $14 \mathrm{ml} / \mathrm{kg} 5 \%$ dextrose over 16 hours. For continuation of NAC as adjuvant therapy for hepatic failure, it should be given at $150 \mathrm{mg} / \mathrm{kg}$ per 24 hours [11].

Topics malnourished or those with glutathione depletion have a higher risk to paracetamol poisoning than others [12]. In these subjects at risk it is recommended to administer NAC even when the serum level in paracetamol is below the values considered toxic [12].

\section{Conclusion}

Errors in drug delivery may be responsible for serious accidents especially for children. In the case of paracetamol overdose, the toxic hepatitis can be serious. It may follow as in the present case, cholestasis characterized by increases in alkaline phosphatase. The administration of paracetamol antidote proved very beneficial as 
levels of liver enzymes in the blood have returned to normal values.

\section{Acknowledgement}

The authors are grateful to P Afoutou, R Doglo and K Konon of the Medico-Social Center of Police (Lomé-Togo).

\section{References}

1. Penna A, Buchanan N (1991) Paracetamol poisoning in children and hepatotoxicity. Br J Clin Pharmacol. 32 :143-149.

2. Gilman AG, Goodman LS, Rall TW, et al. (1985) The pharmacological basis of therapeutics. $7^{\text {th }}$ Ed. New York: Macmillian Publishing Company 622-625.

3. Viala A, Botta A (2005) Toxicologie: Paracetamol. 2e Ed Lavoisier 739-741.

4. Makin AJ, Wendon J, Williams R (1994) Management of severe cases of paracetamol overdosage. BR J Hosp Med 52: 210-13.

5. Moulin M, Coquerel A (2002) Pharmacologie. Abrégés, connaissances et pratique. Masson $2^{\mathrm{e}}$ édition. 572-583.

6. Pajoumand A, Jalali N, Abdollahi M, Shadnia S (2003) Successful treatment of acetaminophen overdose associated with hepatic failure. Hum Exp Toxicol 22: 453-458.

7. Diallo A, Gbeassor M, Vovor A, Eklu-Gadegbeku K, Aklikokou K, et al. (2008) Effect of Tectona grandis on phenylhydrazine-induced anaemia in rats. Fitoterapia 79: 332-336.

8. Schmidt LE, Dalhoff K (2004) Hyperamylasaemia and acute pancreatitis in paracetamol poisoning. Aliment Pharmacol Ther 20: 173-179.

9. Hastier P, Demarquay JF, Maes B (1996) Acute pancreatitis induced by codeine-acetaminophen association: Case reports with positive re-challenge. Pancreas 13: 324-363.

10. Benjamin N, Rawlins M, Vale JA (2002) Drug therapy and poisoning. In: Kumar $\mathrm{P}$, Clark M, editors. Kumar and Clark. Clinical Medicine. $5^{\text {th }}$ ed. United Kingdom: WB Saunders 985-987.

11. Kozer E, Koren G (2001) Management of paracetamol overdose: current controversies. Drug Saf 24: 503-512.

12. Wallace $\mathrm{Cl}$, Dargan PI, Jones AL (2002) Paracetamol overdose: an evidence based flowchart to guide management. Emerg Med J 19: 202-205. 